\title{
The Effect of GENTING Booklet in Stunting Prevention on Knowledge, Attitude, and Behavior of Adolescent Mothers
}

\author{
Monalisa Putri ${ }^{1}$, Kustati Budi Lestari ${ }^{2 *}$ \\ \{ monaliput@gmail.com ${ }^{1},{\text { kustatibudilestari@uinjkt.ac.id }{ }^{2}}_{\text {\} }}$ \} \\ *corresponding author
}

\begin{abstract}
Nursing Study Program, Faculty of Health Sciences, UIN Syarif Hidayatullah JakartaCiputat, 15419, Indonesia ${ }^{1,2}$
\end{abstract}

\begin{abstract}
Risk factors that contribute to the stunting prevalence include adolescent marriage, hygiene practices, and insufficient healthy houses. This condition is compounded by the lack of knowledge and behavior of young mothers related to stuntingprevention. A lot of efforts have been taken as one of them is to help solving this problem by using the GENTING booklet. The purpose of this study was to increase the knowledge, attitude, and behavior of adolescent mothers to prevent stunting. The pre-experimental research with one group pre-test and post-test were used with purposive sampling in a total of 33 adolescent mothers as respondents and using GENTING bookletand questionnaires as instruments. The Wilcoxon test revealed a significant value on knowledge, attitudes, and behavior, $p=0.000(p<0.05)$. Therefore, it can be concluded that the education with GENTING booklet affected the knowledge, attitude, and behaviorof the adolescent mothers. The GENTING booklet can be used as a health promotion media as a means to prevent stunting.
\end{abstract}

Keywords: Adolescent Mothers, Attitude, Behavior, Booklet, Knowledge

\section{Introduction}

A child growth is influenced by the nutrition of children, maternal nutrition, the environment of care, and socio-economic matter. Limited food supply affects the growth of children so children can experience stunting. This condition is a long-term lack of protein intake which is characterized by a lack of height according to age [1].

Children who are stunted are children with a Z-score less than $-2 \mathrm{SD}$ according to WHO calculations. The phenomenon of stunting currently regarded as a problem in the world, especially in Asia (55\%). Indonesia is a country in Southeast Asia with the 3rd highest prevalence of stunting (36.4\%). The prevalence of stunting in Indonesia was $30.8 \%$ [2].

Early pregnancy, anemia in pregnant women, and premature pregnancy are among the factors that cause the high rate of stunting in Indonesia $[3,4]$. This condition is contributed by the high rate of female adolescent marriage in Indonesia (67\%) [5]. Mothers who become pregnant during adolescence usually occur in people with low economic and educational status [6]. Poverty and low education can cause low hygiene and environmental sanitation behavior. Water, sanitation, and hygiene affect the nutritional status of stunting through infectious diseases such as diarrhea and intestinal worm infections $[7,8,9,10]$. 
The incidence of stunting in Tangerang City in 2017 was 23\%. Neglasari Subdistrict was chosen as the research site because of the high risk of stunting, such as high poverty and diarrhea (73\%) [11]. Interviews and observations from 5 adolescent mothers showed that $60 \%$ still lack of knowledge about stunting and hygiene practices.

Prevention of stunting in this area can be done by promoting health using Gerakan Melawan Stunting (GENTING) booklet and e-learning by utilizing the video call feature on Whatsapp. Health promotion using booklet media has been proven effective in increasing knowledge and attitudes [12,13]. The lack of knowledge, attitude, and behavior of adolescent mothers caused researchers to be interested in researching the knowledge, attitude, and behavior after being given health education using the GENTING booklet in the Working Area of Neglasari Public Health Center.

\section{$2 \quad$ Method}

This research used quantitative research with a pre-experimental design and one group pretest-posttest. This research was conducted from 19 May to 11 June 2020 in the Neglasari District Region. The sample in this study was 33 respondents and purposive sampling were used as techniques to obtain subjects who have some certain characteristics. The inclusion criteria in this study were adolescent mothers who have children $(0-2$ years $)$ and live in the area of-Neglasari Public Health Center and were willing to be the respondents. The exclusion criteria in this study were adolescent mothers who were unable to read and did not have a cellphone.

The instruments in this study were questionnaires and a booklet. There are three questionnaires used, they were the questionnaire for knowledge, attitudes, and behavior. The validity test in this questionnaire used the content validity test by experts and the productmoment correlation test. The question item is proven valid if the $r$ obtained is greater than the $\mathrm{r}$ table ( $\mathrm{r}$ result $>0.349$ ). The reliability test results with KR-20 for the knowledge variable were 0.81 and the Cronbach's Alpha results were 0.624 for the attitude questionnaire, and 0.659 for the behavior questionnaire. The GENTING booklet material are gathered from several studies and WHO [14]. The material in this booklet includes the definition of stunting, the causes of stunting, the effect of Water, Sanitation, and Hygiene (WASH) on stunting, the impact of stunting, and the prevention of stunting. Questionnaires were distributed via a google form and booklet via WhatsApp.

The research processes started with distributing an informed consent and a time contract with the respondent through WhatsApp. After that, the researchers distributed questionnaires via google form for the pretest. After the pretest was conducted, the researchersdistributed the booklet in pdf format via WhatsApp to respondents and they red it for 15 minutes. Then, the researchers conducted e-learning about explanation the contents of the booklet to respondents by utilizing the video call feature on WhatsApp. Posttest for all respondents was performed three weeks later to measure memory retention after the intervention. All data were analyzed through SPSS software. Data analysis in this study was univariate and bivariate using the Wilcoxon nonparametric test because the data were not normally distributed. 


\section{Result}

Respondent Characteristics

Table 1. Characteristics of Respondents based on Age

\begin{tabular}{lcccc}
\hline Mean & Median & Modus & SD & Min-Max \\
\hline 20.08 & 20 & 21 & 0.950 & $18-21$ \\
\hline
\end{tabular}

Based on table 1, the majority of respondents were 21 years old.

Table 2. Characteristics of Respondents Based on Education Background

\begin{tabular}{lll}
\hline Level of education & $\mathrm{n}$ & $\%$ \\
\hline No school & - & - \\
Primary School/equivalent & 11 & 33.3 \\
Junior High School/ equivalent & 4 & 12.1 \\
Senior High School/ equivalent & 18 & 54.6 \\
Total & 33 & $100 \%$ \\
\hline
\end{tabular}

Based on table 2, the education background taken by most respondents was senior high school as many as 16 respondents $(48.5 \%)$.

Table 3. Characteristics of Respondents Based on Family Income

\begin{tabular}{ccc}
\hline \multicolumn{2}{c}{ Table 3. Characteristics of Respondents Based on Family Income } \\
\hline Family Income (Rupiah) & $\mathrm{n}$ & $\%$ \\
\hline 4.1 million & 25 & 75.8 \\
$>4.1$ million & 8 & 24.2 \\
Total & 33 & 100 \\
\hline
\end{tabular}

Based on table 3, the majority of respondents have a family income of $<4.1$ million, 25 respondents $(75.8 \%)$.

Table 4. Characteristics of the respondents' children

\begin{tabular}{clcccc}
\hline \multicolumn{7}{c}{ Table 4. Characteristics of the respondents' children } & \\
\hline Variable & Mean & Median & Modus & SD & Min-Max \\
\hline Age & 9.12 & 8 & 5 & 5.644 & $3-24$ \\
Body length & 69.27 & 68 & 75 & 7.859 & $58-88$ \\
\hline
\end{tabular}


Table 5. Frequency Distribution =

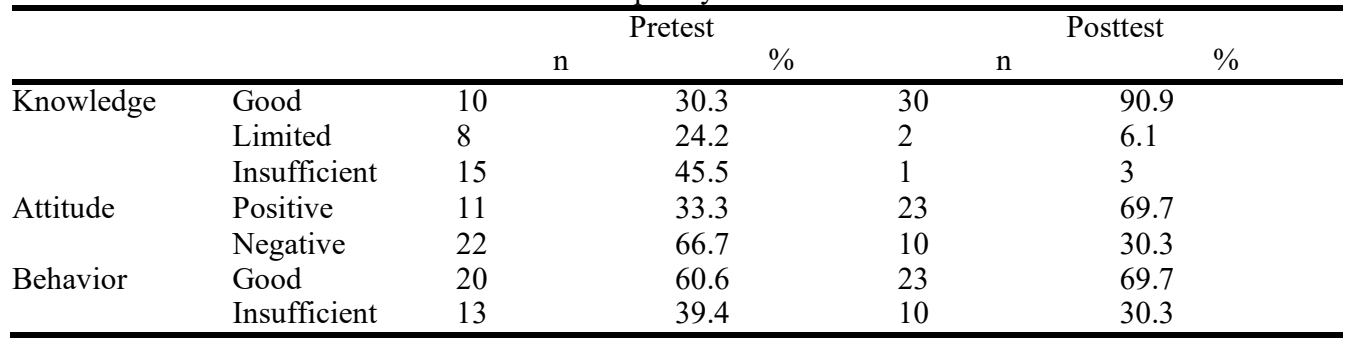

Based on table 54, it can be seen that the majority of respondents have children aged 5 months and a body length of $75 \mathrm{~cm}$.

Table 6. Analysis of the Effect of Health Education Using GENTING Booklet on Knowledge, Attitude, and Behavior

\begin{tabular}{llllc}
\hline & & \multicolumn{1}{c}{ Mean } & P-Value & Z \\
\hline Knowledge & Pre Test & 9.82 & 0.000 & -4.585 \\
& Post Test & 12.94 & & \\
Attitude & Pre Test & 32.70 & 0.000 & -4.597 \\
& Post Test & 38.03 & & \\
Behavior & Pre Test & 32.33 & \multirow{2}{*}{0.000} & -3.919 \\
& Post Test & 35.61 & & \\
\hline
\end{tabular}

Based on table 6, Tthe majority of respondents had insufficient knowledge, as many as 15 respondents $(45.5 \%)$ in the pretest result. In the posttest results, respondents in the insufficient category experienced a reduction to 1 respondent (3\%). The majority of respondent's attitudes were negative as many as 22 respondents $(66.7 \%)$. In the posttest results, respondents in the negative category decreased to 10 respondents $(30.3 \%)$. In the pretest results, the majority of behavior was good as many as 20 respondents $(60.6 \%)$ and experienced an increase in the posttest results to $69.7 \%$.

Based on table 6 , the $p$-value of knowledge, attitude, and behavior $=0.000(p<0.05)$. So it can be concluded the education with the GENTING booklet affected the knowledge, attitude, and behavior of the adolescent mothers.

\section{Discussion}

\section{RESPONDENT CHARACTERISTIC}

\section{Age of Mothers}

The number of respondents in the insufficient category on the three variables may be caused by a lack of a mother's maturity level in thinking as well as a lack of motivation. This is in line with other research which states that the score of knowledge of care, feeding, cognitive and socio-emotional scores in adolescent mothers is lower than adult mothers [15] and adolescent mothers usually occur in populations with insufficient economies so they tend to have low education and it causes low knowledge of mothers in caring for children [6]. 


\section{Education Background}

The low value of knowledge, attitudes, and behavior were dominated by respondents with primary school education. Individuals with high levels of education are easier to absorb information [16]. The level of education affects dietary consumption patterns through food selection and processing. The higher education level, the better mothers can understand food selection and processing [17].

\section{Family Income}

The majority of respondents had family income less than the minimum payment of region. This may be due to many teenagers who still depend their economy on their parents and they are still unable to meet the nutritional needs of their children. Adolescent mothers have lower education than adult mothers, which causes low socio-economic levels. The low level of the economy can result in inadequate fulfillment of children's nutritional needs and low hygiene and environmental sanitation behavior [6].

\section{Characteristics of Children}

The majority of respondents have children ranging from 3 to 24 months. The children generally enter the golden period in child development, namely the first 1.000 days of life. The nutrition that a child obtains at this age will affect the health and well-being of the child in the future. Nutritional deficiencies in the first 1.000 days of life have long-lasting effects that are difficult to correct after a child is 2 years old. Inappropriate height is a sign of insufficient nutrition in children [20]. Children with stunting have less cognitive development than children who are not stunting [21,22]. Based on the body length that researchers asked their mothers, it could be concluded that the majority of children had body length with Z-Score $<-1$ SD which means the children have not been categorized as stunting. 


\section{THE EFFECT OF HEALTH EDUCATION ON CHANGES IN KNOWLEDGE}

The average value of the good category in knowledge increased after health education was carried out by $31 \%$ in this study. It can be caused by a large number of respondents who paid attention and red the booklet. Increased knowledge can also be affected by the desire of the respondent to know, understand, and believe information about stunting prevention efforts following the theory of Notoatmodjo regarding the domain of knowledge, namely knowing and understanding/believing [23].

The effectiveness of booklet media in increasing knowledge in this study can be caused by the distribution of booklet via WhatsApp media which is a message application owned by all respondents so that booklet can be read at any time. It is also caused by an explanation of the booklet material through the video call feature on WhatsApp. E-learning has the benefit of being easier to understand because it uses multimedia (images and text) and is more effective and efficient because learning can be done anywhere and anytime without limited space and time.

\section{THE EFFECT OF HEALTH EDUCATION ON CHANGES IN ATTITUDE}

The average value of the positive attitude increased after the intervention by $10 \%$. The increase in positive category may be caused the adolescent mothers know the benefits of the booklet. The increase in the average value of attitudes after health education is in line with other research which proves that there was an increase in the average value of attitudes after being given health education using WhatsApp media and booklet [12]. Research by Puspitaningrum also proves that the value of attitude increases by $8 \%$ after being given health education [24].

Attitudes towards stunting describe the perceptions of mothers about the impactsof stunting on their children, which consists of negative and positive attitudes [25]. However, good knowledge does not always lead to a good attitude. This can be shown from the results of this study where the value of knowledge is high, there were still negative attitudes. This may be caused by other factors including a lack of motivation from inside and outside the respondent or the knowledge gained has not been able to create a comprehensive understanding/belief in the material.

\section{THE EFFECT OF HEALTH EDUCATION ON CHANGES IN BEHAVIOR}

Based on the research results, the average value of behavior in the good category has increased by $10 \%$. It can be caused by the presence of communication/counseling (predisposing factors were age, knowledge, attitudes, and traditions), enabling factors (availability of information sources or facilities), and reinforcing factors (attitudes and behavior of health workers, religious leaders) [26].

This change in behavior values is in line with other research which experienced an increase in behavior by $38.8 \%$ after being given health education [27] and also shows differences in the behavior scores of the control and intervention groups before and after health education using booklet media [28]. Increased knowledge can affect attitudes to be better. This attitude is then implemented in the respondent's behavior in a healthy behavior [26].

Increasing the value of knowledge in this study may be raise awareness the respondents to change behavior according to their knowledge because the higher the knowledge, the more likely the behavior will change for the better. The increase in the mean value of behavior which 
is not significant in the results of this study can be caused bythe limitations of researchers who only use recall questionnaires and do not observe respondent's behavior during the study.

\section{Conclusion}

The average score of good knowledge, positive attitude, and good behavior was increased by $31 \%, 10 \%$, and $10 \%$ after intervention with GENTING booklet. Based on the statistics test, there was a significant effect of health education using the GENTING booklet on knowledge, attitude, and behavior $(\mathrm{p}=0.000)$. Therefore, it can be concluded that the education with the GENTING booklet affected the knowledge, attitude, and behavior of the adolescent mothers. Booklet proved to be effective and efficient method because learning booklet in cellphones can be done anywhere and anytime without limited space and time. Nursing Education Institutions are expected to continue to develop a curriculum regarding methods for health promotion, especially online and offline learning media regarding stunting and how to prevent it for mothers and teenage students.

\section{References}

[1] Azmi, U. \& Mundiastuti, L. Konsumsi zat gizi pada balita stunting dan non stunting di Kabupaten Bangkalan. Amerta Nutrition. 2018; 2(3): 292-298.

[2] Kementerian Kesehatan RI. Situasi balita pendek (stunting) di Indonesia. Jakarta : Kemenkes RI; 2018.

[3] World Health Organization. Global nutrition target 2025 stunting policy brief. Geneva: WHO; 2012.

[4] Larasati, D.A., Nindya, T.S., Arief, Y.S. Hubungan antara kehamilan remaja dan riwayat pemberian ASI dengan kejadian stunting pada balita di Wilayah Kerja Puskesmas Pujon Kabupaten Malang. Amerta Nutrition. 2018; 2(4): 392 - 401.

[5] Badan Pusat Statistik Indonesia \& UNICEF. Kemajuan yang tertunda : analisis data perkawinan usia anak di Indonesia. Jakarta: BPS; 2016.

[6] Wemakor, et al. Young maternal age is a risk factor for child undernutrition in Tamale Metropolis, Ghana. BMC Journal. 2018; 11:877. https://doi.org/10.1186/s13104-0183980-7

[7] Desyanti, C. \& Nindya, T.S. Hubungan riwayat penyakit diare dan praktik higiene dengan kejadian stunting pada balita usia 24 - 59 bulan di Wilayah Kerja Puskesmas Simolawang Surabaya. Amerta Nutrition. 2017; 1(3): 243 - 251.

[8] Torlesse, H., et al. Determinants of stunting in indonesian children: evidence from a croos-sectional survey indicate a prominent role for the water, sanitation and hygiene sector in stunting reduction. BMC Public Health. 2016; 16: 669. https://doi.org/10.1186/s12889-016-3339-8.

[9] Sinatrya, A.K. \& Muniroh, L. Hubungan faktor water, sanitation, and hygiene (wash) dengan stunting di Wilayah Kerja Puskesmas Kotakulon, Kabupaten Bondowoso. Amerta Nutrition. 2019; 3(3): 164 - 170.

[10] Alwabr \& Al Moayed. Prevalence of intestinal parasitic infections among school children of Al-Mahweet Governorate, Yemen. European Journal of Biological Research. 2016; 6(2): $64-73$. 
[11] Badan Pusat Statistik Kota Tangerang. Kecamatan neglasari dalam angka 2019. Tangerang : BPS Kota Tangerang; 2019.

[12] Algafi, Al., Hidayat, Lina. Pengaruh Penggunaan Media Sosial Whatsapp dan Booklet Terhadap Pengetahuan Dan Sikap Siswa Tentang Rokok Di SMA Negeri 13 Medan. Jurnal Muara. 2019; 3(2): $281-290$.

[13] Pratiwi, Y.F. \& Puspitasari, D.I. Efektivitas penggunaan media booklet terhadap pengetahuan gizi seimbang pada ibu balita gizi kurang di Kelurahan Semanggi Kecamatan Pasar Kliwon Kota Surakarta. Jurnal Kesehatan. 2017; 10(1): 58 - 67.

[14] WHO \& UNICEF. Improving nutrition outcomes with better water, sanitation and hygiene : practical solutions for policies and programmes. Switzerland: WHO; 2015.

[15] Widyaningrum, R. Perbedaan pengetahuan dan praktik pemberian makan serta perkembangan anak 6-24 bulan pada ibu usia remaja dan dewasa. Jurnal Gizi Klinik Indonesia. 2016; 13 (1): $27-33$.

[16] Olsa, ED., Sulastri \& Anas E. Hubungan sikap dan pengetahuan ibu terhadap kejadian stunting pada anak baru masuk sekolah dasar di Kecamatan Nanggalo. Jurnal Kesehatan Andalas. 2017; 6 (3).

[17] Yuliana, W. \& Hakim, B.N. Darurat stunting dengan melibatkan keluarga. Takalar : Yayasan Ahmar Cendekia Indonesia; 2019.

[18] Ali, M. Memahami riset perilaku dan sosial. Bandung : Pustaka Cendekia Utama; 2011.

[19] Budiman \& Riyanto. Kapita selekta kuesioner pengetahuan dan sikap dalam penelitian kesehatan. Jakarta: Salemba Medika; 2014.

[20] Hanindita, M. Tanya jawab tentang nutrisi di 1.000 hari pertama kehidupan anak. Jakarta: Gramedia Pustaka Utama; 2018.

[21] Pantaleon, M.G, Hamam, H., Indria, L.G. Stunting berhubungan dengan perkembangan motorik anak. Jurnal Gizi dan Dietetik Indonesia. 2015; 3(1): 12 - 15.

[22] Aryastami \& Ingan, T. Kajian kebijakan dan penanggulangan masalah gizi stunting di Indonesia. Penelitian Kesehatan. 2017; 45(4): 234.

[23] Notoatmodjo, S. Promosi kesehatan teori dan aplikasinya. Jakarta: Rineka Cipta; 2010.

[24] Puspitaningrum, et al. Pengaruh media booklet terhadap pengetahuan dan sikap remaja putri terkait kebersihan dalam menstruasi di Pondok Pesantren Al-Ishlah Demak Triwulan II Tahun 2017. JKM UNDIP. 2017; 5 (4): 274 - 281.

[25] Haines, A.C., et al. Analysis of rural indonesian mothers's knowledge, attitudes, and beliefs regarding stunting. KEI Journals. 2018; 6(11): $1-13$.

[26] Notoatmodjo, S. Ilmu perilaku kesehatan. Jakarta: Rineka Cipta; 2014.

[27] Sulastri. Pengaruh pendidikan kesehatan terhadap sikap dan perilaku personal hygiene gigi dan mulut anak usia sekolah di SD Negeri Payung. Jurnal Care. 2018; 6(1): 92 101.

[28] Natalansyah \& Nyamin, Y. Peran booklet terhadap pengetahuan, sikap, perilaku jumantik-psn dan keberadaan jentik di Panarung, Kota Palangka Raya. JPPNI. 2020; 4(3): $150-161$. 